\title{
The Corona Virus Pandemic and Global Transformations: Making or Breaking International Orders?
}

\author{
Greg SIMONS \\ PhD \\ University of Canterbury, Private Bag 4800, Christchurch 8140, Canterbury, New \\ Zealand; \\ Associate Professor (Docent) in Political Science \\ Uppsala University, IRES, Box 514, SE-751 20, Uppsala, Sweden; \\ Associated Researcher \\ Diplomatic Academy of the Ministry of Foreign Affairs of the Russian Federation, \\ 119021, Ostozhenka St., 53/2, bldg 1, Moscow, Russian Federation; \\ Researcher \\ Uppsala University (Sweden), Turiba University (Latvia), Ural Federal University \\ (Russian Federation) \\ E-mail: gregmons@yahoo.com \\ ORCID: 0000-0002-6111-5325
}

CITATION: Simons G. (2020) The Corona Virus Pandemic and Global Transformations: Making or Breaking International Orders? Outlines of Global Transformations: Politics, Economics, Law, vol. 13, no 5, pp. 20-37. DOI: 10.23932/2542-0240-2020-13-5-2

Received: 12.08.2020.

\begin{abstract}
In the period of the $21^{\text {st }}$ century leading up to the Corona Virus pandemic, there was increasing consensus that the global order that had existed since the end of the Cold War and the collapse of the Soviet Union where the unipolar hegemony of the United States was in relative decline, weakening and transforming. It was transforming from a unipolar to multipolar order, of course, the US was not going to leave the transformation uncontested in order to retain its privileged global position. The Corona Virus outbreak was a black swan event, it is also being used by various international actors to leverage opportunities caused by the weaknesses exposed in this extraordinary time. The US has been acting in an aggressive manner during the pandemic in an effort to try and weaken opponents and coerce friends in order to 'cancel'
\end{abstract}

the pre-Corona Virus global transformations and retain its global hegemony.

KEY WORDS: global transformation, unipolar world order, multipolar world order, Corona Virus (COVID-19), international relations

\section{Introduction}

There has been a gradual growing consensus that the global order is in a state of transformation, from the unipolar hegemony of the United States that has existed since the end of the bipolar world order that existed during the Cold War, moving towards a post-Western multipolar global order [Lukyanov 2010; Chebankova 2017; 
Simons, Kukartseva 2019; Cooley, Nexon 2020]. Rising powers were increasingly challenging the US hegemony at different levels (local, regional and global) and in different spheres (foreign policy, defence and security policy, public diplomacy, international institutions, technology and finance). Various key international and regional actors have been traditionally labelled as being hostile to the United States and its interests, such as Cuba, Iran, Russia and Venezuela. Increasingly attention has turned to and focused on China, the primary global competitor, together with attempts to coerce China in a disadvantageous position that would limit its opportunities to challenge the US.

The sudden appearance of the Corona Virus, which make a spectacular and devastating appearance and influence on all aspects of globalisation and international relations can be considered by some, but not others, to be a black swan event [Fishman 2020]..$^{1}$ Whether or not it is an actual Black Swan event or not is of lesser significance, than the subjective political ability and motivation to construct the appearance of one. As there are opportunities to be more readily accessible in extraordinary times than in ordinary ones as the existing rules of the game become frayed in an unstable physical environment that lacks coherent informational flows and possesses high levels of cognitive uncertainty and risk. The effects of COVID-19 have been predicted as being potentially significant and long lasting [Heisbourg 2020]. Other observers and commentators note some transformations are already occurring in international affairs [Simon 2020] and the implications for global leadership and the global order [Zhao 2020].
Given the risks to US global hegemony and its unipolar order during the recent pre-COVID-19 era and the decreasing opportunities for defending this position during 'ordinary' situations (non-crisis) in international relations, there is the motivation and temptation to use these extraordinary circumstances as a means to consolidate and strengthen the US position and to potentially weaken the position of challengers and rivals. Can the US use the extraordinary circumstances of the Corona Virus pandemic to 'cancel' the transformation of the global order from unipolar to multipolar, and retain its hegemony?

This paper consists of three sections, the first section concerns establishing the method and theory that is used by the author to collect and inform the data that has been analysed on the road to answering the research question. The second section concerns an overview of the arguments concerning the nature of the transformation of the international order before the outbreak of COVID-19. This is to give a theoretical and practical background to measure the sense and direction of material appearing in the third section, which concerns the topic of tracking the arguments on how and/or if COVID-19 can be or is being used to reshape the configuration of the global order.

\section{Method and Approach}

The approaches to textual analysis shall include content analysis (quantifications of different elements in text), argumentation analysis (the structure of argumentation used), and the qualitative analysis of ideas in the content (with a fo-

\footnotetext{
1 A black swan event is defined as being:"First, it is an outlier, as it lies outside the realm of regular expectations, because nothing in the past can convincingly point to its possibility. Second, it carries an extreme'impact.'Third, in spite of its outlier status, human nature makes us concoct explanations for its occurrence after the fact, making it explainable and predictable." For more see: McGillivray G. (2020) Corona Virus Is Significant, but Is It a True Black Swan Event? The Conversation. Available at: https://theconversation.com/ coronavirus-is-significant-but-is-it-a-true-black-swan-event-136675, accessed 15.10.2020.
} 
cus on geopolitical frames) [Boréus, Bergström 2017, pp. 7-9]. The combination of these approaches is expected to yield results on the ontology (what exists) and epistemology (knowledge and how we 'know' things) of academic and mass mediated textual depictions in a literature review of the use of how the Corona Virus COVID-19) is or has transformed existing global geopolitical orders. The objects of study include power, people, policy, norms and values, international relations and geopolitics ${ }^{2}$ and so forth [Boréus, Bergström 2017, pp. 1-2]. The academic and popular texts then contextualise the relationships according to perceived and projected power in the constructed social world order of mankind, such as justice and injustice, powerful and powerless, legitimate and illegitimate, worthy and unworthy.

It is the intention of the author to use a qualitative approach to analysing the data, and given the size of the samples, to create an indicative study. Where the qualitative study intends to capture the complexity of the object(s) of study [Hyett, Kenny, Dickson-Swift 2014, p. 2]. The empirical material shall be analysed via framing theory. Entman [Entman 2004, p. 5] defines framing as "selecting and highlighting some facets of events or issues, and making connections among them so as to promote a particular interpretation, evaluation, and/ or solution." There are a number of basic functions that are performed by frames covering political events, issues and actors: "defining effects or conditions as problematic; identifying causes; conveying a moral judgement; endorsing remedies or improvements" [Entman 2004, p. 5]. These approaches shall form the backbone to the literature review method.
Literature reviews play an important role as a foundation for all types of research, where they can serve as the basis for knowledge development. As such they can form the basis of future research and theory [Snyder 2019, p. 339]. A review potentially enables a synthesis of state of the art knowledge, which in turn enables the prospect to quality and relevance of the research evidence to date [Gough 2007]. There are a variety of ways and means to engage in a literature review. For example, a structured literature review or a semistructured literature review or a scoping study. A structured literature review that offers a summary of a number of different studies and could draw some conclusions. Whereas a systematic review "is a specific, carefully defined approach to the literature review", and it is argued that this method should only be applied when they can provide valid means to summarise the literature [Bearman et al. 2012, p. 638]. The favoured approach of this paper is a semistructured literature review [Mullins, Spence 2003; Pawar, Spence 2003], which seeks the definition and transforming global orders within the subject area of geopolitics during the COVID-19 pandemic of academic and popular text.

This is to be conducted as a scoping study, which is defined as aiming to rapidly map key concepts circulating in a research area, along with the main types and sources of evidence available. It is of value and use where an area is complex and/ or never reviewed comprehensively before. There are at least four possible reasons for undertaking a scoping study: as a means to examine the extent, range and nature of research activity; to determine the value of undertaking a full systematic review; to summarise and disseminate research find-

\footnotetext{
2 Here geopolitics is understood and used in the sense of the political regulation and management of the struggle and competition in interests and objectives between and among members of the international community in their practice of international relations and affairs.
} 
ings; and to identify existing gaps in existing research. This paper's motivation is found in the first and last reasons.

A computerised search was conducted on the Google (for popular sources) and Google Scholar (for academic sources) database that used the following key words: corona virus and international relations; corona virus and geopolitics. This sample was further supplemented by books on the subject from the library of the author, and the examples were manually checked against the stipulated textual criteria at the beginning of this section for relevance. A total sample of 53 were collected and analysed in the process.

\section{Brief Overview of Literature on Global Transformations Before COVID-19}

This section is intended to provide the reader with a brief overview of the transformations and evolutions that were occurring in the international system before the advent of the Coronavirus pandemic in order to give a background to the theoretical and pragmatic logic of words and deeds occurring in the global information space since the pandemic. Increasingly in the $21^{\text {st }}$ century, observers and authors have concluded that there is a transformation of global geopolitics. The assessments tend to vary in the breadth and depth of the transformations from a post-Cold War unipolar order with the United States as the hegemon, and heading towards another configuration. Cooley and Nexon [Cooley, Nexon 2020] argue that this trend has been occurring for some years and predates Trump's presidency (although they state he has accelerated the transformation) as the United States has gradually dismantled the instruments and mechanisms of its hegemony that were laid in the aftermath of the Second World War. They also go as far as to claim that the US can no longer be la- belled as a global hegemon, although it is at this stage still the single most powerful nation in the international system. As a result there is a gradual evolution and transformation towards a multipolar global order with a variety of varied international powers vying for positions of influence and power, and allies of the US taking more independent policy stances. This relative decline of the US leaves it unable to broker effective alliances and allows challenges to wedge existing aspects of the US power base.

There are two different and yet related hegemonic relative declines that are transforming global politics and geopolitics. One is the decline of the global liberal hegemony that is being challenged by non-liberal political forces that are domestic and international actors. The other is the relative decline of the US unipolar geopolitical hegemony, both of these evolutions have been occurring for some time and have become more noticeable since the Global War On Terrorism and the socalled New Cold War [Simons, Kukartseva 2019]. As noted by Cooley and Nexon [Cooley, Nexon 2020] the relative decline of US unipolar hegemony has been the result of a mix of internal and external factors. Ikenberry and Nexon [Ikenberry, Nexon 2019, p. 421] note the upholding of a hegemonic order requires "a rich array of relations and articulated roles and evolving identities, which give hegemony its life and operation." Weaker and weakening actors as well as at times hegemons face a number of problems in power projection. "They not only structure international order but find themselves structured by it. In this sense, hegemonic orders are not simply a reflection or crystallisation of the distribution of power" (Ibid.). As such, the situation has created an environment of increased competition and conflict with various issues how to create strategies to maximise the newly emerging opportunities. 
Indications of the transformation of the global order are increasingly being understood as the evolution from a unipolar to a multipolar global order [Lukyanov 2010; Cooper, Flemes 2013; Petito 2016; Chebankova 2017]. This implies the need to adapt to the evolving global environment in terms of foreign policy and strategy. Cooper and Flemes [Cooper, Flemes 2013, p. 958] note that there has been much commentary on the role of emerging states in terms of influence and effect, although this is far from being clearly understood. They also note the rise of significance and importance the role of national interest and the decline of values. This is seen in the gradual disintegration of value-driven communities and arguments. "The camps of debate over particular issue areas, over values such as legitimacy or responsibility or national sovereignty and the future order as a whole will not always be delineated along the lines of liberal democracies versus autocracies or the West versus the rest" [Cooper, Flemes 2013, p. 958]. The quality and quality of the new order is currently being 'negotiated'.

Petito [Petito 2016] argues that the global transformation not only includes the evolution towards a multipolar configuration of world powers, but there is an evolution away from a Western-centric system. As such the global transformation is moving towards a multipolar and multicivilizational global order. This brings problems in its own right as it requires an effective mechanism and genuine dialogue of civilisations in order to avoid or at least minimise misunderstandings and any possible conflicts that could emerge as a result.

Concretely, this neo-regionalist, multipolar, and cross-cultural model of world order would be different from the Huntingtonian model of multi-civilizational-multipolar order as: (i) it is not shaped along civilisational-culturalist lines but by a dialogical multiculturalism, (ii) it is based on new forms of cross-cultural regionalism and negotiation of a new crosscultural jus gentium, and (iii) it is committed to the widespread process of "intercivilizational mutual understanding" at multiple levels" [Petito 2016, p. 88].

This quote implies that there needs to be a new system of communicating and interacting in the transforming international system, one which is more complex than the current Western-centric system. To realise this, there needs to be a reconfiguration of the present system to accommodate for these future needs, an action that will likely further reduce US power and influence in the international system. Strategies to achieve these ends can include challengers wedging US global networks and institutions and brokering new global networks and institutions that compete. The emergence of such networks and institutions as BRICS, the Shanghai Cooperation Organisation and others serve just this purpose. Soft balancing is the primary means, which does not directly challenge the US military's tangible dominance, but rather using non-military tools to delay, frustrate or undermine unilateral policies [Flemes 2013, p. 1020]. Of importance is the ability to influence and alter the established global orthodoxy of word and deed that is used to prop up hegemonic power and influence. Furthermore, the factors that are identified as possibly explaining the influence of state actors in a "multipolar order are: relative material, ideational and institutional capabilities. Foreign policy strategies are the vehicles by which to convert these capabilities into political influence" [Flemes 2013, p. 1029]. The relative decline of the US has created opportunities for various sets of state and nonstate actors to emerge in the growing global disorder.

Schweller [Schweller 2011] argued that the relative decline of the US is likely irreversible (in agreement with Cool- 
ey and Nexon's assessment). Adding further, although not yet at the point of collapse, other emerging non-Western powers such as China and India are likely to be in a position to set the stage for a fundamental rethinking and practice of world politics in their image. There are a number of great powers set to challenge US power and influence more openly and with greater effect. This is like to create a qualitative change in the expected behaviour of the emergent great powers [Schweller 2011, p. 295; Mukherjee 2020]. Interestingly, Flemes [Flemes 2013, p. 1032] predicted that a selfish style of leadership in the US would greatly weaken their position and encourage friend and foe alike to, "in the medium term exert leverage from their privileged network positions to replace formal institutions with substitution networks." One can argue, as Cooley and Nexon [Cooley, Nexon 2020], this situation was achieved with the so-called Trump doctrine when applied to foreign policy.

This leaves great power actors, such as Russia, challenges and dilemmas as to how to conceive this new order conceptually and how to respond to it pragmatically. For example, the current transformation process is seen as two quite distinctive paradigmatic positions. The current unipolar hegemony champions cultural, economic and political globalisation under the leadership and control of the Western world, and the US in particular. The multipolar position advocates for a more particularistic approach that strives for a balance of interests, multiplicity of politico-cultural forms and multiple centres of international influence [Chebankova 2017, p. 217]. The practical policy problem is how to maximise the opportunities and simultaneously hedge against possible threats in such an unstable and dynamic global environment. One of the avenues was to join global liberal organisations and institutions, such as the World Trade Organisation and APEC and be able to have an influence in these Western dominated political spaces. Another means was to co-create alternative international institutions that support the multipolar vector, such as the SCO and BRICS [Lukyanov 2010]. This strategy fits with the idea of wedging against the influence of the US unipolar global order and in brokering an institutional framework that can assist and support a multipolar order. It is the author's understanding that these alternative groups and platforms are not intended to overthrow the US-led, Western-centric version of globalisation, but as a means to co-opt globalisation and transform it to a non-Western-centric multipolar global order. This requires careful and deliberate long-term planning and the ability to factor in black swan events, such as that of the Coronavirus pandemic.

\section{COVID-19 and Global Transformations}

The effects of COVID-19 on all spheres of human life and activity at all levels has become a very rapid and invasive event. There were several observed broad strategies applied that focused on: 1) economic security; 2) human security; and 3) state security, which involve opportunity costs when applied on a zero sum game basis. This includes human security at the level of civil liberties and individual freedoms, where governments have imposed or through the use of fear created an exchange of these freedoms and liberties for an illusion of security against the virus [Brzechczyn 2020; Cherkaoui 2020; Simon 2020]. Economic transformations are also very noticeable, even in countries that prioritised economic security, where the mantra and practice of economic globalisation was severely disrupted that has caused massive economic devastation to countries in turns of economic down turn, job losses, growing debt crisis and the devastation of small 
businesses [Cherkaoui 2020; Figus 2020; Grinin, Korotayev 2020; Reinhart C., Reinhart V. 2020]. ${ }^{3}$ The general economic devastation has been contrasted by the rapidly rising fortunes of the super-rich that have accumulated massive sums of money during the pandemic. ${ }^{4}$ There has also been the focus on state security, which has manifested itself in various ways that include increased protectionism, nationalism and geopolitical competition. This is the focus of the rest of this section.

\section{GEOPOLITICAL TRANSFORMATIONS}

With the emergence and rapid spread of COVID-19 globally, different countries were left scrambling for varied strategies to mitigate its effects in an increasingly unstable global environment [Mayilvaganan 2020]. COVID-19 has been characterised as a globally transforming event, which at its most basic level represents an open-ended crisis [Blackwill, Wright 2020; Fishman 2020, p. 5; Allan et al. 2020]. ${ }^{5}$ One of the predictions has been that the great powers that lack a growing population and a growing economy shall be weakened by COVID-19, and that countries such as China and Russia stand a chance to temporarily benefit from the pandemic conditions [Grinin, Korotayev 2020, p. 9; Scocozza 2020]. In response to this, the US and other global great powers are likely to engage in increasingly hostile foreign policy, such as the current vector of US anti-Chinese policy [Grinin, Korotayev 2020, p. 11]. Bremmer [Bremmer
2020, p. 17] predicts three factors are shaping the transformation of the global order during the pandemic: deglobalisation, rising populism and nationalism, and a rising China. These events, trends and processes are driven and directed by actors' cognitive assessments and evaluations of people, places and occurrences within the physical domain via representations and knowledge from the information domain. As Biscop [Biscop (2) 2020, p. 231] points out, COVID-19 is a symmetrical threat as it potentially hits everyone and the effects are related to the health of the population, health infrastructure, the resolution and speed of the crisis response.

Objectively speaking, this situation gives a potential advantage to great powers, such as China, US, Russia and others as they can mobilise more resources than lesser powers [Farias 2020]. In reference to the increased great power rivalry of the $21^{\text {st }}$ century, COVID-19 did not change this pattern, "instead, many powers instrumentalise the crisis to compete with each other" (Ibid.). ${ }^{6}$ Several trends have been noted: strengthening of the state in a context of de-globalisation (the undoing of the liberal global order created in the wake of World War Two); the acceleration of competition between major power; and the rise of an aggressive form of information warfare [Von Hlatky et al. 2020, p. 1]. There has also been the prediction that the coming period of geopolitical realignments shall intensify the global race for critical minerals [Kalantzakos 2020]. Depending on how ef-

\footnotetext{
3 Stiglitz J., Rashid H. (2020) A Global Debt Crisis Is Looming - How Can We Prevent It? The Guardian, August 3, 2020. Available at: https://www.theguardian.com/business/2020/aug/03/global-debt-crisis-relief-coronavirus-pandemic, accessed 15.10.2020. 4 Rogers T.N. (2020) American Billionaires Have Gotten Half a Trillion Richer During the Pandemic, but the Country's Racial Wealth Gap Has Grown, Too. Business Insider, June 4, 2020. Available at: https://www.businessinsider.com/billionaires-got-565-billion-richerduring-the-coronavirus-pandemic-2020-6? r=US\&IR=T, accessed 15.10.2020.

5 Natalucci M. (2020) International Affairs and the Global Geopolitical Order after the Coronavirus. International Insider, March 2, 2020. Available at: https://internationalinsider.org/international-affairs-and-the-global-geopolitical-order-after-coronavirus/; Davis W. (2020) The Unravelling of America. Rolling Stone, August 6, 2020. Available at: https://www.rollingstone.com/politics/politicalcommentary/covid-19-end-of-american-era-wade-davis-1038206/, accessed 15.10.2020.

6 Janparvar M. (2020) Different Attitudes of Political Geography and Geopolitics to Coronavirus. Modern Diplomacy, April 15, 2020. Available at: https://moderndiplomacy.eu/2020/04/15/different-attitudes-of-political-geography-and-geopolitics-to-coronavirus/, accessed 15.10.2020.
} 
fectively or ineffectively they manage their own recovery, the result can maintain the balance of power or alter it. The lack of certainty concerning the effects and duration of COVID-19 means that situations can rapidly change one direction and then all of a sudden, go in another completely different one, which makes any one theoretical construct problematic in terms of deriving accurate and meaningful predictions. This can shape how a state perceives and responds to the pandemic. ${ }^{7}$ Actors respond to events by how they predict the 'reality' on the ground.

Some hold out a measure of positive expectations for the West to survive. For example, the EU's policy response to the effects of COVID-19 has been hailed as extraordinary. Yet at the same time, reservations are expressed as this will require a significant and fundamental internal and external overhaul of the EU, together with possible 'teething' problems. ${ }^{8}$ Some of the caveats include, although Europe is a relatively rich market and modern part of the world, with somewhat effective governance and living standards, none of this was ever translated in to foreign policy acumen. This is especially evident with no apparent contingency for when Pax Americana ends in Europe and globally [Bremmer 2020, p. 22; Koenig, Stahl 2020, pp. 3-4]. ${ }^{9}$ Certainly, the pandemic potentially presents the EU with some opportunities, but only if there is close proximity between internal unity and co- hesion, together with the ability to globally project power [Koenig, Stahl 2020, pp. 12]. Predictions also include a weakened EU owing to the continued fracturing that was occurring before the pandemic owing to issues such as economic crises and the migrant crisis, COVID-19 adds to these substantial existing points of contention. ${ }^{10}$ Given the recent history to date on these aspects, there is an element of doubt as to whether the EU can capitalise on possible opportunities.

Friedman [Friedman 2020, p. 24] identifies four distinct systems simultaneously operating in the US concerning efforts at containing the effects of COVID-19: the medical, the economic, the social, and the geopolitical. It is evident that the US has attempted to instrumentalise the pandemic crisis as a means to protect its privileged, but declining, global geopolitical position. One such example is the rapid increase of military activity and coercion in its attempt to apply the policy of "maximum pressure" against Iran and reduce Iranian influence in the region, rather than solidarity with the region against the effects of COVID-19, which some view as being a lost opportunity to put aside geopolitical aims and to tangibly demonstrate good will [Cole 2020]. The rise of China's global economic and military power and influence has been under increasing scrutiny for some years (one can point to Obama's "Asia Pivot" as an expression of this) and has been the cause for concern, owing to

7 Rausch T. (2020) What if the COVID-19 World Is What States Make of It? New Perspectives on Global Economic Dynamics, April 16, 2020. Available at: https://ged-project.de/globalization/what-if-the-covid19-world-is-what-states-make-of-it/; Johnston S.A. (2020) The Pandemic and the Limits of Realism. Foreign Policy, June 24, 2020. Available at: https://foreignpolicy.com/2020/06/24/ coronavirus-pandemic-realism-limited-international-relations-theory/; McTague T. (2020) The Pandemic's Global Aftershocks Are Coming. The Atlantic, May 18, 2020. Available at: https://www.theatlantic.com/international/archive/2020/05/coronaviruspandemic-second-wave-geopolitics-instability/611668/, accessed 15.10.2020.

8 Damjanovic I., de Sadeleer N. (2020) Could Coronavirus Strengthen Rather Than Threaten Geopolitical Europe? International Affairs, June 11, 2020. Available at: www.internationalaffairs.org.au/australianoutlook/could-the-coronavirus-strengthen-ratherthan-threaten-geopolitical-europe/, accessed 15.10.2020.

9 Techau J. (2020) Saving Europe from Corona's Nasty Geopolitics. EU Observer, April 15, 2020. Available at: https://euobserver.com/ opinion/148057, accessed 15.10.2020.

10 Geopolitics After COVID-19: Is the Pandemic a Turning Point? (2020). The Economist Intelligence Unit, April 1, 2020. Available at: https://country.eiu.com/article.aspx?articleid=1339299717\&Country=Albania\&topic=Politics\&subtopic=Forecast\&subsubtopic=Int ernational+relations, accessed 15.10.2020. 
the relative decline of the US. It has been calculated that the pandemic maybe an opportunity to destroy Chinese soft power and remove this risk based on shaping global public perception and opinion on the Chinese handling of the pandemic and the risks posed [Bremmer 2020, pp. 1517; Mandelbaum 2020]. Although there are some signs that the US lacks its former ability to broker agreements, such as Secretary of State Mike Pompeo's attempt to force a joint G7 statement that included a reference to the "Wuhan virus", which all allies refused to endorse [Bremmer 2020, p. 19]. US isolation and withdrawal into a more self-centred focus is being intensified by the pandemic's global repercussions.

There is a strong feeling and perception among international relations scholars in the US that the US is not leading the pandemic crisis response, which is something that is costing reputation, although predicting there will be little impact and change to the global order in the end. ${ }^{11}$ Fundamental questions have been raised on the effects of COVID-19 that call into question the current iteration of globalisation and the neoliberal ideology that has developed with it, especially after the rapid breakdown of global governance in face of the virus [Borrell 2020]. As such, a chain of events and reactions have been unleashed. The US and European Union have been attempting to use COVID-19 not to undo the effects of globalisation, which supports the continued hegemony of the US and liberalism
[Biscop (1) 2020, p. 234], ${ }^{12}$ but rather to reorganise the institutions and relational aspects of globalisation in order to reduce the power and influence of China and preserve the Western dominance in the global system. The stakes of appropriate and correct crisis management strategies have been laid out by numerous commentators.

The COVID-19 crisis is holding up a mirror to Western countries - making us realise that the perception we have of ourselves might be distorted. The crisis will be a huge test: our effectiveness in managing it could alternately accelerate or slow the de-Westernisation of the world. In any case, it will challenge globalisation and rearrange the world order. ${ }^{13}$

Long lasting negative effects have been predicted that shall result from poor geopolitical strategy and the ineffective management of politics and the economy. This can potentially include the quicker fragmentation of regional blocs with incomplete integration; and US-China friction moving towards a deeper 'Cold War' that will have the effect of dividing the world into opposing camps. ${ }^{14}$ Richard Horton (editor of Lancet) argues that the anti-Chinese rhetoric and actions are disproportionate and risk global stability even further during a period of instability, and are used to mask the West's failures in managing the pandemic. ${ }^{15}$ This manifests itself in a number of ways, for example the global

\footnotetext{
11 Drezner D.W. (2020) So What Do International Relations Scholars Think About COVID-19 and World Politics? The Washington Post, May 11, 2020. Available at: https://www.thewashingtonpost.com/outlook/2020/05/11/so-what-do-international-relations-scholarsthink-about-covid-19-world-politics/, accessed 15.10.2020.

12 Perthes V. (2020) The Corona Crisis and International Relations: Open Questions, Tentative Assumptions. German Institute for International and Security Affairs, March 31, 2020. Available at: https://www.swp-berlin.org/en/publication/the-corona-crisis-and-international-relations-open-questions-tentative-assumptions/, accessed 15.10.2020.

13 López J. (2020) The Coronavirus: A Geopolitical Earthquake. European Council on Foreign Relations, April 2, 2020. Available at: https://www.ecfr.eu/article/commentary_the_coronavirus_a_geopolitical_earthquake, accessed 15.10.2020.

14 Malik H. (2020) Geopolitics after COVID-19: US-China Cold War, Fragmented EU and GCC. Tellimer, April 20, 2020. Available at: https://tellimer.com/article/geopolitics-in-em-after-covid-19-us-china-col, accessed 15.10.2020.

15 Horton R. (2020) This Wave of Anti-China Feelings Masks the West's Own COVID-19 Failures. The Guardian, August 3, 2020. Available at: https://www.theguardian.com/commentisfree/2020/aug/03/covid-19-cold-war-china-western-governments-international-peace, accessed 15.10.2020.
} 
race to create a vaccine by the great powers, and the notion of 'vaccine nationalism' where the rule of first in first served applies at the expense of notions and concepts as global solidarity. ${ }^{16}$ Stability if not checked can generate the spread of its effects to other sectors and regions.

The chain-effect of the initial health nature of the pandemic crisis has evolved to include additional elements of the crisis in politics and the economic. Economic hardship and political instability in the West, and particularly in the US is hastening the geopolitical decline and this in turn is creating and shaping the domestic politics of geopolitical confrontation. For example, the increasingly aggressive use of economic and military instruments of coercion against China, which is increasing the risk of violent regional confrontations. ${ }^{17}$ Andrés Ortega assesses the current global pandemic situation as potentially accelerating the de-Westernisation process, responses at best can slow down, but cannot be reversed with the use of the crisis. Not least owing to internal divisions within the Western elite. ${ }^{18}$ This is in part owing to not only the use of resources, but about prioritising these resources in times of scarcity. China and Russia have been more skilled and systematic in managing resources to expand their geopolitical influence and global reach. ${ }^{19}$ This situation creates motive and opportunity to challenge and transform the global architecture.

Given the apparent signs of fragmentation, weakness and absence of global leadership, emerging powers at the local, regional and global levels are likely and more able to assert influence via hard and soft power means. ${ }^{20}$ This is, for example, seen in the search for economic opportunities by China and India in the Middle East region, both 'newcomers' in comparison to leading Western countries [Sevilla 2020]. Russia and China have been active in initiating humanitarian diplomacy in the form of aid to various countries, including Italy and on the African continent, to boost its global soft power. This goal has been further assisted by the absence of the US in regions such as Africa [Biscop (1) 2020, p. 2; Bremmer 2020; Heisbourg 2020; Morillas 2020; Zhao 2020]. ${ }^{21}$ In fact, China was noted as beginning to embody the values of solidarity and cooperation that were historically associated with the West, while the US and core Western countries were all but absent. ${ }^{22}$ Chinese humanitarian diplomacy in Africa demonstrates an approach where it projects an image as a defender of the developing world [Koenig, Stahl 2020,

16 Yang W. (2020) Is the US-China Rivalry Tangling a Coronavirus Vaccine With Geopolitics? Deutsche Welle, June 22, 2020. Available at: https://www.dw.com/en/is-the-us-china-rivalry-tangling-a-coronavirus-vaccine-with-geopolitics/a-53896712, accessed 15.10.2020.

17 Khan H.A. (2020) The Oil and Coronavirus Crises May Hasten US Geopolitical Decline. Al Jazeera, June 13, 2020. Available at: https://www.aljazeera.com/opinions/2020/6/13/the-oil-and-coronavirus-crises-may-hasten-us-geopolitical-decline/, accessed 15.10.2020.

18 Ortega A. (2020) Geopolitics after COVID 19: Conflict or Cooperation? The Globalist, June 21, 2020. Available at: https://www.theglobalist.com/coronavirus-pandemic-covid19-geopolitics-united-states-europe-china/, accessed 15.10.2020.

19 Techau J. (2020) Saving Europe From Corona's Nasty Geopolitics. EU Observer, April 15, 2020. Available at: https://euobserver.com/ opinion/148057, accessed 15.10.2020.

20 Geopolitics After COVID-19: Is the Pandemic a Turning Point?(2020). The Economist Intelligence Unit, 1 April 1, 2020. Available at: https://country.eiu.com/article.aspx?articleid=1339299717\&Country=Albania\&topic=Politics\&subtopic=Forecast\&subsubtopic=International+relations, accessed 15.10.2020.

21 Perthes V. (2020) The Corona Crisis and International Relations: Open Questions, Tentative Assumptions. German Institute for International and Security Affairs, March 31, 2020. Available at: https://www.swp-berlin.org/en/publication/the-corona-crisis-and-international-relations-open-questions-tentative-assumptions/; Moisi D. (2020) The Coronavirus, a Geopolitics of Fears. Institut Montaigne, March 17, 2020. Available at: https://www.institutmontaigne.org/en/blog/coronavirus-geopolitcs-fears, accessed 15.10.2020. 22 López J. (2020) The Coronavirus: A Geopolitical Earthquake. European Council on Foreign Relations, April 2, 2020. Available at: https://www.ecfreu/article/commentary_the_coronavirus_a_geopolitical_earthquake, accessed 15.10.2020. 
pp. 6-7]. From an Italian perspective, it was noted that they received aid from China, Cuba and Russia before their allies or the EU, which can potentially redefine political relationships. ${ }^{23}$ The Chinese global humanitarian diplomacy efforts have even generated conjecture as to whether this will be a 'Chinese Marshall Plan' (after the US aid efforts to Western Europe in the wake of World War Two). ${ }^{24}$ However, exact predictions are difficult to make in such an unstable political, economic and geopolitical global environment, and trends may constantly alternate and change.

Certainly US global primacy is being challenged by the absence of its leadership, which potentially opens the field to other actors, such as China [Campbell, Doshi 2020; Dobrescu, Ciocea 2020, p. 134]. If China is able to emerge from the accusations of guilt and responsibility for the pandemic, it can potentially take the position of global leader. Although this will be challenging and qualitatively different from the current configuration and conceptualisation. China's economic and military power are certainly global. However, there may be challenges in brokering political consent for its global leadership. ${ }^{25}$ Thus the failure of the US will tangibly (by creating a physical vacuum) and intangibly (by removing cognitive impediments to challengers) encourage an open challenge to US global leadership. In the run-up to the 2020 US presidential elections, the division and split between the different domestic political visions of the role to be played by the country is apparent and caught between recent historical role references and the opportunities and threats created by the Coronavirus. These visions, which can be roughly characterised as being 'America first' versus US as a global unipolar hegemon, are incompatible with a lack of middle ground or compromise considered or even possible.

\section{Conclusion}

In the introduction of this paper, a provocative question was posed for academic inquiry. Can the US use the extraordinary circumstances of the Corona Virus pandemic to 'cancel' the transformation of the global order from unipolar to multipolar, and retain its hegemony? In way of a short answer, yes the US has attempted to do so. This was seen in its attempt to use COVID-19 to apply maximum pressure on Iran and pressure the government into making concessions, which has failed. The US also tried to use COVID-19 as a means to further pressure China, a continuation of the tense and dangerous pre-pandemic geopolitics that included economic (trade war) and military coercion (military exercises and implied use of military hardware such as B-52 bombers). Once more, this has failed as well. This is in no small part owing to the declining economic and military strength and soft power appeal of the US, even among its own allies, let alone those designated as enemy states. The growing self-centred and asymmetrical nature of US foreign policy and diplomacy (i.e. making one-sided 'deals' and breaking agreements) has damaged and tarnished the credibility and reliability of the US and its global role.

\footnotetext{
23 Romito M. (2020) EU: Corona Virus and Geopolitics. An Italian Perspective. University of Navarra, April 20, 2020. Available at: https://www.unav.edu/web/global-affairs/detalle/-/blogs/eu-corona-virus-and-geopolitics-an-italian-perspective, accessed 15.10.2020. 24 Schmidhuber J. (2020) Coronavirus Geopolitics: Germs and the Rise of Empires. Available at: http://people.idsia.ch/ juergen/coronavirus-geopolitics-chinese-marshall-plan.html, accessed 15.10.2020.

25 Kirecci M.A. (2020) New Geopolitics in a Post-Coronavirus World. Politics Today, June 3, 2020. Available at: https://politicstoday.org/new-geopolitics-in-a-post-coronavirus-world/; Cabestan J-P. (2020) China's Battle With Coronavirus: Possible Geopolitical Gains and Real Challenges. Al Jazeera Centre for Studies, April 19, 2020. Available at: https://studies.aljazeera.net/en/reports/ china\%E2\%80\%99s-battle-coronavirus-possible-geopolitical-gains-and-real-challenges, accessed 15.10.2020.
} 
However, not everything always depends and works off the US global agen$\mathrm{da}$, especially in the period of their relative global decline as the unipolar hegemon and a less Western centric multipolar order takes shape. Rising powers at local, regional and global levels are increasingly contesting US dictates and interests, such as China, Iran, Russia and Turkey. These challenges occurred before the pandemic, but the West's response (namely EU and US) have shown significant shortcomings and weaknesses that are encouraging further challenge. The poor allocation and use of resources, and application of inappropriate strategies have created opportunities that can be capitalised upon by those countries better able to adapt and mobilise in these new global conditions. Many observers and commentators are predicting that COVID-19 will not likely alter the current global transformations, but likely intensify and accelerate those transformations, which is a reasonable assumption given the current vector taken by actors and events.

\section{References}

Allan J. et al. (2020) How the World Will Look after the Coronavirus Pandemic. Foreign Policy, March 20, 2020. Available at: https:/foreignpolicy.com/2020/03/20/ world-order-after-coroanvirus-pandemic/, accessed 15.10.2020.

Bearman M., Smith C.D., Carbone A., Slade S., Baik C., Hughes-Warrington M., Neumann D.L. (2012) Systematic Review Methodology in Higher Education. Higher Education Research \& Development, vol. 31, no 5, pp. 625-640. DOI: $10.1080 / 07294360.2012 .702735$

Biscop S. (1) (2020) Coronavirus and Power: The Impact upon International Politics, Security Policy Brief 126, Brussels: Egmont Royal Institute for International Relations.

Biscop S. (2) (2020) Weaker Together or Weaker Apart? Great Power Re- lations after the Coronavirus. Asia Europe Journal, 18, pp. 231-234. DOI: $10.1007 / \mathrm{s} 10308-020-00582-3$

Blackwell R.D., Wright T. (2020) The End of World Order and American Foreign Policy, Council Special Report No. 86, New York: Council on Foreign Relations.

Boréus K., Bergström G. (2017) Analysing Text and Discourse: Eight Approaches for the Social Sciences, Thousand Oaks (CA): Sage Publishing

Borrell J. (2020) The Post-Coronavirus World is Already Here. Politique Etrangere, no 2, pp. 9-23.

Bremmer I. (2020) Coronavirus and the World Order. Horizons: Journal of International Relations and Sustainable Development, no 16, Pandemics \& Geopolitics: The Quickening, pp. 14-23.

Brzechczyn K. (2020) The Coronavirus in Liberal and Illiberal Democracies and the Future of the Globalised World. Society Register, vol. 4, no 2, pp. 83-94. DOI: $10.14746 /$ sr.2020.4.2.06

Campbell K.M., Doshi R. (2020) The Coronavirus Could Reshape Global Order: China is Manoeuvring for International Leadership as the United States Falters. Foreign Affairs, March 18, 2020. Available at: https://www.foreignaffairs.com/ node/1125706, accessed 15.10.2020.

Chebankova E. (2017) Russia's Idea of the Multipolar World Order: Origins and Main Dimensions. Post-Soviet Affairs, vol. 33, no 3, pp. 217-234. DOI: 10.1080/1060586X.2017.1293394

Cherkaoui M. (2020) The Shifting Geopolitics of Coronavirus and the Demise of Neoliberalism (Part 2). Al Jazeera, March 22, 2020. Available at: https://studies.aljazeera.net/en/reports/shifting-geopolitics-coronavirus-and-demise-neoliberalism-\%E2\%80\%93-part-2, accessed 15.10.2020.

Cole J. (2020) Missed Opportunities: The Trump Administration, Iran, and the Coronavirus Pandemic. Gulf Insights Series. No. 31, College of Arts and Sciences, Qatar 
University. Available at: http://www.qu.edu. qa/static_file/qu/research/Gulf\%20Studies/ documents/Gulf\%20Insights\%2031.pdf, accessed 15.10.2020.

Cooley A., Nexon D. (2020) Exit from Hegemony: The Unravelling of the American Global Order, New York: Oxford University Press.

Cooper A.F., Flemes D. (2013) Foreign Policy Strategies of Emerging Powers in a Multipolar World: An Introductory Review. Third World Quarterly, vol. 34, no 6, pp. 943-962. DOI: 10.1080/01436597.2013.802501

Dobrescu P., Ciocea M. (2020) This Time Is Different. The Globalisation of Uncertainty. Romania Journal of Communication and Public Relations, vol. 22, no 1(49), pp. 129-136. Available at: https://www.ceeol.com/search/article-detail id=857282, accessed 15.10.2020.

Entman R.M. (2004) Projections of Power: Framing News, Public Opinion, and U.S. Foreign Policy, Chicago: University of Chicago Press.

Farias H.C. (2020) Geopolitics and National Defence Capabilities: A Look at the Emerging Scenario in Pandemic Times. $\mathrm{Ob}$ servatório Militar da Praia Vermelha, April 8, 2020. Available at: http://ompv.eceme. eb.mil.br/seguranca-publica-e-crime-organizado-internacional/100-areas-tematicas/ geopolitica-e-defesa/a-pandemia-e-a-ordem-mundial-sob-a-perspectiva-da-defesa/240-geopolitics-and-national-defensecapabilities-a-look-at-the-emerging-scenario-in-pandemic-times, accessed 15.10.2020.

Femes D. (2013) Network Powers: Strategies of Change in the Multipolar System. Third World Quarterly, vol. 34, no 6, pp. 1016-1036. DOI: $10.1080 / 01436597.2013 .802504$

Figus A. (2020) Coronavirus COVID-19, a Complex Issue between Health, Economy, Politics, and Communication. Geopolitical, Social Security and Freedom Journal, vol. 3, no 1, pp. 1-13. DOI: 0.2478/gssfj-2020-0001
Fishman J. (2020) "This is Different" - The Coronavirus Pandemic as a "Transforming Event". Israel Journal of Foreign Affairs, vol. 14, no 1, pp. 3-7. DOI: $10.1080 / 23739770.2020 .1763028$

Friedman G. (2020) The Corona Virus and Geopolitical Impact. Horizons: Journal of International Relations and Sustainable Development, no 16, Pandemics \& Geopolitics: The Quickening, pp. 24-29.

Gough D. (2007) Weight of Evidence: A Framework for the Appraisal of the Quality and Relevance of Evidence. Research Papers in Education, vol. 22, no 2, pp. 213228. DOI: $10.1080 / 02671520701296189$

Grinin L., Korotayev A. (2020) COVID-19 Pandemic, Geopolitics, and Recession. WP 4, Moscow: International Centre for Education and Social and $\mathrm{Hu}$ manitarian Studies.

Heisbourg F. (2020) From Wuhan to the World: How the Pandemic Will Reshape Geopolitics. Survival, vol.62, no 3, pp.7-24. DOI: $10.1080 / 00396338.2020 .1763608$

Hughes G. (2020) War in the Grey Zone: Historical Reflections and Contemporary Implications. Survival, vol. 62, no 3, pp. 131158. DOI: $10.1080 / 00396338.2020 .1763618$

Hyett N., Kenny A., Dickson-Swift V. (2014) Methodology or Method? A Critical Review of Qualitative Case Study Reports. International Journal of Qualitative Studies on Health and Well-Being, vol. 9, no 1. DOI: 10.3402/qhw.v9.23606

Ikenberry G.J., Nexon D.H. (2019) Hegemony Studies 3.0: The Dynamics of Hegemonic Orders. Security Studies, vol. 28, no 3, pp. 395421. DOI: $10.1080 / 09636412.2019 .1604981$

Kalantzakos S. (2020) The Race for Critical Minerals in an Era of Geopolitical Realignments. The International Spectator: Italian Journal of International Affairs, vol. 55, no 3, pp. 1-16. DOI: 10.1080/03932729.2020.1786926

Koenig N., Stahl A. (2020) How the Coronavirus Pandemic Affects the EU's Geopolitical Agenda, Policy Paper, Berlin: Hertie School Jaques Delors Centre. 
Lukyanov F. (2010) Russia’s Dilemmas in a Multipolar World. Journal of International Affairs, vol. 63, no 2, pp. 19-32. Available at: https://publications.hse.ru/ mirror/pubs/share/folder/w84bhrdbyj/direct/159705545.pdf, accessed 15.10.2020.

Mandelbaum M. (2020) China's Challenge: The Geopolitics of the Coronavirus. The American Interest, March 24, 2020. Available at: https://www.the-american-interest.com/2020/03/24/the-geopolitics-of-the-coronavirus/, accessed 15.10.2020.

Mayilvaganan M. (ed.) (2020) COVID-19 Pandemic in the Indo-Pacific: How the Countries are Dealing Amidst Changing Geopolitics, Bangalore (India): National Institute for Advanced Studies.

Morillas P. (2020) Coronavirus: Between the Global and the National. CIDOB Opinion. No. 615. Available at: https://www.cidob.org/en/publications/ publication_series/opinion/seguridad_y_ politica_mundial/coronavirus_between the_global_and_the_national, accessed 15.10.2020.

Mukherjee R. (2020) Chaos as Opportunity: The United States and World Order in India's Grand Strategy. Contemporary Politics, vol. 26, no 4, pp. 420-438. DOI: 10.1080/13569775.2020.1777040

MullinsS.,SpenceS.A.(2003) Re-Examining Thought Insertion: Semi-Structured Literature Review and Conceptual Analysis. British Journal of Psychiatry, no 182, pp. 293-298. DOI: 10.1192/bjp.182.4.293

Pawar A.V., Spence S.A. (2003) Defining Thought Broadcast: Semi-Structured Literature Review. British Journal of Psychiatry, no 183, pp. 287-291. DOI: 10.1192/bjp.183.4.287

Petito F. (2016) Dialogue of Civilisations in a Multipolar World: Toward a Multicivilisational-Multiplex World Order. International Studies Review, no 18, pp. 78-91. DOI: 10.1093/isr/viv030

Reinhart C., Reinhart V. (2020) The Pandemic Depression: The Global Econ- omy Will Never be the Same. Foreign Affairs, November/December 2020. Available at: https://www.foreignaffairs.com/ articles/united-states/2020-08-06/coronavirus-depression-global-economy, accessed 15.10.2020.

Schweller R. (2011) Emerging Powers in an Age of Disorder. Global Governance, no 17, pp. 285-297. DOI: $10.1163 / 19426720-01703002$

Scocozza C. (2020) Coronavirus Geopolitics. A Reflection on the Russian Case. Culture e Studi del Sociale, vol. 5, no 1, pp. 389-393. Available at: http://www.cussoc.it/index.php/journal/article/view/126, accessed 15.10.2020.

Sevilla Jr. H.A. (2020) Middle East Geopolitics and China-India Strategic Interaction in the New Era. The International Spectator: Italian Journal of International Affairs, vol. 14, no 2, pp. 179-193. DOI: $10.1080 / 25765949.2020 .1760541$

Simon S. (2020) Subtle Connections: Pandemic and the Authoritarian Impulse. Survival, vol. 62, no 3, pp. 103-111. DOI: $10.1080 / 00396338.2020 .1763615$

Simons G., Kukartseva M.A. (2019) New Cold War and the Crisis of the Liberal Global Order. Outlines of Global Transformations: Politics, Economics, Law, vol. 12, no 3, pp. 77-93. DOI: 10.23932/2542-0240-2019-12-3-77-93

Snyder H. (2019) Literature Review as a Research Methodology: An Overview and Guidelines. Journal of Business Research, no 104, pp. 333-339. DOI: 10.1016/j.jbusres.2019.07.039

Von Hlatky S., Hollander H., Massie J., Munier M., Skinner S. (2020) The Geopolitical Impact of COVID-19, Policy Brief 1, Network for Strategic Analysis.

Zhao S. (2020) Rhetoric and Reality of China's Global Leadership in the Context of COVID-19: Implications for the USled World Order and Liberal Globalisation. Journal of Contemporary China. DOI: 10.1080/10670564.2020.1790900 


\section{Пандемия коронавируса и глобальные преобразования: создание или нарушение международных порядков?}

\section{Грег САЙМОНС}

кандидат наук

University of Canterbury, Private Bag 4800, Christchurch 8140, Canterbury,

New Zealand;

доцент политических наук

Uppsala University, IRES, Box 514, SE-751 20, Uppsala, Sweden;

ассоциированный исследователь

Дипломатическая академия МИД России, 119021, ул. Остоженка, д. 53/2, стр. 1,

Москва, Российская Федерация;

исследователь

Uppsala University (Sweden), Turiba University (Latvia), Ural Federal University

(Russian Federation)

E-mail: gregmons@yahoo.com

ORCID: 0000-0002-6111-5325

\section{ЦИТИРОВАНИЕ: Simons G. (2020) The Corona Virus Pandemic and Global Transformations: Making or Breaking International Orders? Outlines of Global Transformations: Politics, Economics, Law, vol. 13, no 5, pp. 20-37. \\ DOI: 10.23932/2542-0240-2020-13-5-2}

Статья поступила в редакцию 12.08.2020.

АННОТАЦИЯ. В ХХІ столетии в период, предшествовавший пандемии коронавируса, все чаще звучали утверждения, что глобальный порядок с постепенно угасавщей однополярной гегемонией Соединенных Штатов, который сложился после окончания холодной войны и в результате распада Советского Союза, якобы ослабевал и трансформировался. Глобальный порядок из однополярного преобразовывался в многополярный. Естественно, США не собирались оставлять эту трансформацию без внимания и стремились сохранить свое привилегированное положение на международной арене. Вспьшка коронавируса стала подтверждением теории «черного ле- бедя». Различные международные субъекты воспользовались теми возможностями, что открылись перед ними в связи с начавщейся эпидемией. США во время пандемии действовали агрессивно, пьтаясь ослабить противников и повлиять на друзей, дабы обратить вспять фундаментальные соицально-политические трансбормаиии и сохранить свою глобальную гегемонию.

КЛЮЧЕВЫЕ СЛОВА: глобальная трансбормачия, однополярный миропорядок, многополярный миропорядок, коронавирус (COVID-19), международнье отночения 


\section{Список литературы}

Allan J. et al. (2020) How the World Will Look after the Coronavirus Pandemic // Foreign Policy, March 20, 2020 // https://foreignpolicy.com/2020/03/20/ world-order-after-coroanvirus-pandemic/, дата обращения 15.10.2020.

Bearman M., Smith C.D., Carbone A., Slade S., Baik C., Hughes-Warrington M., Neumann D.L. (2012) Systematic Review Methodology in Higher Education // Higher Education Research \& Development, vol. 31, no 5, pp. 625-640. DOI: 10.1080/07294360.2012.702735

Biscop S. (1) (2020) Coronavirus and Power: The Impact upon International Politics, Security Policy Brief 126, Brussels: Egmont Royal Institute for International Relations.

Biscop S. (2) (2020) Weaker Together or Weaker Apart? Great Power Relations after the Coronavirus // Asia Europe Journal, 18, pp. 231-234. DOI: $10.1007 / \mathrm{s} 10308-020-00582-3$

Blackwell R.D., Wright T. (2020) The End of World Order and American Foreign Policy, Council Special Report No. 86, New York: Council on Foreign Relations.

Boréus K., Bergström G. (2017) Analysing Text and Discourse: Eight Approaches for the Social Sciences, Thousand Oaks (CA): Sage Publishing

Borrell J. (2020) The Post-Coronavirus World is Already Here // Politique Etrangere, no 2, pp. 9-23.

Bremmer I. (2020) Coronavirus and the World Order // Horizons: Journal of International Relations and Sustainable Development, no 16, Pandemics \& Geopolitics: The Quickening, pp. 14-23.

Brzechczyn K. (2020) The Coronavirus in Liberal and Illiberal Democracies and the Future of the Globalised World // Society Register, vol. 4, no 2, pp. 83-94. DOI: $10.14746 /$ sr.2020.4.2.06

Campbell K.M., Doshi R. (2020) The Coronavirus Could Reshape Global Or- der: China is Manoeuvring for International Leadership as the United States Falters // Foreign Affairs, March 18, 2020 // https://www.foreignaffairs.com/node/ 1125706, дата обращения 15.10.2020.

Chebankova E. (2017) Russia's Idea of the Multipolar World Order: Origins and Main Dimensions // PostSoviet Affairs, vol. 33, no 3, pp. 217-234. DOI: 10.1080/1060586X.2017.1293394

Cherkaoui M. (2020) The Shifting Geopolitics of Coronavirus and the Demise of Neoliberalism (Part 2) // Al Jazeera, March 22, 2020 // https://studies.aljazeera.net/en/reports/ shifting-geopolitics-coronavirus-and-demise-neoliberalism-\%E2\%80\%93-part-2, дата обращения 15.10.2020.

Cole J. (2020) Missed Opportunities: The Trump Administration, Iran, and the Coronavirus Pandemic // Gulf Insights Series. No. 31, College of Arts and Sciences, Qatar University // http://www.qu.edu.qa/ static_file/qu/research/Gulf\%20Studies/ documents/Gulf\%20Insights\%2031.pdf, дата обращения 15.10.2020.

Cooley A., Nexon D. (2020) Exit from Hegemony: The Unravelling of the American Global Order, New York: Oxford University Press.

Cooper A.F., Flemes D. (2013) Foreign Policy Strategies of Emerging Powers in a Multipolar World: An Introductory Review // Third World Quarterly, vol. 34, no 6, pp. 943-962. DOI: $10.1080 / 01436597.2013 .802501$

Dobrescu P., Ciocea M. (2020) This Time Is Different. The Globalisation of Uncertainty // Romania Journal of Communication and Public Relations, vol. 22, no 1(49), pp. 129-136 // https://www.cee$\mathrm{ol}$.com/search/article-detail? id $=857282$, дата обращения 15.10.2020.

Entman R.M. (2004) Projections of Power: Framing News, Public Opinion, and U.S. Foreign Policy, Chicago: University of Chicago Press.

Farias H.C. (2020) Geopolitics and National Defence Capabilities: A Look at the 
Emerging Scenario in Pandemic Times // Observatório Militar da Praia Vermelha, April 8, 2020 // http://ompv.eceme.eb.mil. $\mathrm{br} /$ seguranca-publica-e-crime-organizado-internacional/100-areas-tematicas/ geopolitica-e-defesa/a-pandemia-e-a-ordem-mundial-sob-a-perspectiva-da-defesa/240-geopolitics-and-national-defensecapabilities-a-look-at-the-emerging-scenario-in-pandemic-times, дата обращения 15.10.2020.

Femes D. (2013) Network Powers: Strategies of Change in the Multipolar System // Third World Quarterly, vol. 34, no 6, pp. 1016-1036. DOI: $10.1080 / 01436597.2013 .802504$

Figus A. (2020) Coronavirus COVID-19, a Complex Issue between Health, Economy, Politics, and Communication // Geopolitical, Social Security and Freedom Journal, vol. 3, no 1, pp. 1-13. DOI: 0.2478/gssfj-2020-0001

Fishman J. (2020) "This is Different" - The Coronavirus Pandemic as a "Transforming Event" // Israel Journal of Foreign Affairs, vol. 14, no 1, pp. 3-7. DOI: $10.1080 / 23739770.2020 .1763028$

Friedman G. (2020) The Corona Virus and Geopolitical Impact // Horizons: Journal of International Relations and Sustainable Development, no 16, Pandemics \& Geopolitics: The Quickening, pp. 24-29.

Gough D. (2007) Weight of Evidence: A Framework for the Appraisal of the Quality and Relevance of Evidence // Research Papers in Education, vol. 22, no 2, pp. 213228. DOI: $10.1080 / 02671520701296189$

Grinin L., Korotayev A. (2020) COVID-19 Pandemic, Geopolitics, and Recession. WP 4, Moscow: International Centre for Education and Social and $\mathrm{Hu}-$ manitarian Studies.

Heisbourg F. (2020) From Wuhan to the World: How the Pandemic Will Reshape Geopolitics//Survival,vol.62, no3,pp.7-24. DOI: 10.1080/00396338.2020.1763608

Hughes G. (2020) War in the Grey Zone: Historical Reflections and Con- temporary Implications // Survival, vol. 62, no 3, pp. 131-158. DOI: $10.1080 / 00396338.2020 .1763618$

Hyett N., Kenny A., Dickson-Swift V. (2014) Methodology or Method? A Critical Review of Qualitative Case Study Reports // International Journal of Qualitative Studies on Health and Well-Being, vol. 9, no 1. DOI: 10.3402/qhw.v9.23606

Ikenberry G.J., Nexon D.H. (2019) Hegemony Studies 3.0: The Dynamics of Hegemonic Orders // Security Studies, vol. 28, no 3, pp. 395-421. DOI: $10.1080 / 09636412.2019 .1604981$

Kalantzakos S. (2020) The Race for Critical Minerals in an Era of Geopolitical Realignments // The International Spectator: Italian Journal of International Affairs, vol. 55, no 3, pp. 1-16. DOI: $10.1080 / 03932729.2020 .1786926$

Koenig N., Stahl A. (2020) How the Coronavirus Pandemic Affects the EU's Geopolitical Agenda, Policy Paper, Berlin: Hertie School Jaques Delors Centre.

Lukyanov F. (2010) Russia's Dilemmas in a Multipolar World // Journal of International Affairs, vol. 63, no 2, pp. 19-32 // https://publications.hse.ru/mirror/pubs/ share/folder/w84bhrdbyj/direct/159705545. pdf, дата обращения 15.10.2020.

Mandelbaum M. (2020) China's Challenge: The Geopolitics of the Coronavirus // The American Interest, March 24, 2020 // https://www.the-american-interest.com/ 2020/03/24/the-geopolitics-of-the-coronavirus/, дата обращения 15.10.2020.

Mayilvaganan M. (ed.) (2020) COVID-19 Pandemic in the Indo-Pacific: How the Countries are Dealing Amidst Changing Geopolitics, Bangalore (India): National Institute for Advanced Studies.

Morillas P. (2020) Coronavirus: Between the Global and the National // CIDOB Opinion. No. 615 // https://www.cidob.org/ en/publications/publication_series/opinion/seguridad_y_politica_mundial/coronavirus_between_the_global_and_the national, дата обращения 15.10.2020. 
Mukherjee R. (2020) Chaos as Opportunity: The United States and World Order in India's Grand Strategy // Contemporary Politics, vol. 26, no 4, pp. 420-438. DOI: $10.1080 / 13569775.2020 .1777040$

MullinsS.,SpenceS.A.(2003) Re-Examining Thought Insertion: Semi-Structured Literature Review and Conceptual Analysis // British Journal of Psychiatry, no 182, pp. 293-298. DOI: 10.1192/bjp.182.4.293

Pawar A.V., Spence S.A. (2003) Defining Thought Broadcast: Semi-Structured Literature Review // British Journal of Psychiatry, no 183, pp. 287-291. DOI: 10.1192/bjp.183.4.287

Petito F. (2016) Dialogue of Civilisations in a Multipolar World: Toward a Multicivilisational-Multiplex World Order // International Studies Review, no 18, pp. 78-91. DOI: 10.1093/isr/viv030

Reinhart C., Reinhart V. (2020) The Pandemic Depression: The Global Economy Will Never be the Same // Foreign Affairs, November/December 2020 // https://www.foreignaffairs.com/articles/ united-states/2020-08-06/coronavirusdepression-global-economy, дата обращения 15.10.2020.

Schweller R. (2011) Emerging Powers in an Age of Disorder // Global Governance, no 17, pp. 285-297. DOI: $10.1163 / 19426720-01703002$

Scocozza C. (2020) Coronavirus Geopolitics. A Reflection on the Russian Case // Culture e Studi del Sociale, vol. 5, no 1, pp. 389-393 // http://www.cussoc.it/index. php/journal/article/view/126, дата обращения 15.10.2020.

Sevilla Jr. H.A. (2020) Middle East Geopolitics and China-India Strategic Interaction in the New Era // The International Spectator: Italian Journal of International Affairs, vol. 14, no 2, pp. 179-193. DOI: $10.1080 / 25765949.2020 .1760541$

Simon S. (2020) Subtle Connections: Pandemic and the Authoritarian Impulse // Survival, vol. 62, no 3, pp. 103-111. DOI: 10.1080/00396338.2020.1763615

Simons G., Kukartseva M.A. (2019) New Cold War and the Crisis of the Liberal Global Order // Outlines of Global Transformations: Politics, Economics, Law, vol. 12, no 3, pp. 77-93. DOI: 10.23932/2542-0240-2019-12-3-77-93

Snyder H. (2019) Literature Review as a Research Methodology: An Overview and Guidelines // Journal of Business Research, no 104, pp. 333-339. DOI: 10.1016/j.jbusres.2019.07.039

Von Hlatky S., Hollander H., Massie J., Munier M., Skinner S. (2020) The Geopolitical Impact of COVID-19, Policy Brief 1, Network for Strategic Analysis.

Zhao S. (2020) Rhetoric and Reality of China's Global Leadership in the Context of COVID-19: Implications for the USled World Order and Liberal Globalisation // Journal of Contemporary China. DOI: 10.1080/10670564.2020.1790900 